\title{
The National Tolerance of Z Generation
}

\author{
Fikri Fauzi Ma'mur ${ }^{1, *}$, Rahmat Rahmat ${ }^{2}$ \\ ${ }^{1,2}$ Universitas Pendidikan Indonesia, Bandung, Indonesia \\ *Corresponding author.Email: fikrifauzimamur07@student.upi.edu
}

\begin{abstract}
This research is motivated by the concept of national tolerance fostered early on by the nation's founders, especially the youth oath fighters have begun to erode, evidenced by the many cases of intolerance that occur among adolescents (Gen$Z$ ). This study aims to find out how the concept of national tolerance is used as a guideline for gen-z in national and state life. This research uses a qualitative approach and case study method with interview, observation, and documentation study data collection. The research results show that Generation $\mathrm{Z}$ has its own uniqueness in terms of tolerance, especially in national tolerance. They realize that they must tolerate, and they realize that they are part of a different group that is united because they have a desire to unite. Problems occur according to them because of the lack of understanding that a person has in solving problems. Gen $\mathrm{Z}$ is a generation that can be said to have 2 different characters, they live in "two" worlds. And they recognize that the digital world has freedom of expression. In the concept of nationhood, they realize the importance of tolerance to maintain unity and integrity. Not all generation $\mathrm{Z}$ has an intolerant attitude, especially in SMA Negeri 4 Bandung acts of intolerance that offend Religion, Ethnicity, Race and Culture are almost not found, but in the context of "joking" racial expressions are still found.
\end{abstract}

Keywords: Generation Z, Nation, Tolerance.

\section{INTRODUCTION}

The freedom fighters and the Founding Fathers have instilled the values of tolerance since the beginning of the struggle for independence. Even before that, in the era of national awakening, the Budi utomo movement and the youth oath event gave a clear picture that the Indonesian nation was built on the basis of a will to be together, not because it had been determined by others.

This effort is certainly based on a high value of tolerance and puts aside ethnocentrism and fanaticism towards an understanding, and prioritizes togetherness, unity and integrity.

Technological developments that occur today have many influences on the paradigm of generation $Z$. The generation that has an important role in welcoming Indonesia Gold 2045 is certainly an important asset that must be maintained and provided with adequate education in the hope that after leading later, they will be able to become a generation of character. and able to compete with the world.
However, their understanding of the concept of tolerance within the national framework deserves attention. Based on a report from CNN Indonesia [1] a student received terror from her friend who is a member of a religious organization at her school through a message on whatsapp, and it has been going on for a long time. This is because the victim does not wear a headscarf at school. This case when linked to one religion (Islam) is certainly not appropriate, because according to Azyumardi Azra's view, Islam is peaceful, tolerant and understands and respects each other, he is more likely that Islam is substantial than just a formality in the form of symbols [2].

This problem certainly deserves our careful attention, according to the research results of the Center for the Study of Islam and Society (PPIM) UIN Syarif Hidayatullah Jakarta which states that at the level of attitudes or opinions of students and students (which in this case is referred to as Generation Z) have a religious view that tend to be radical $(58.5 \%)$ and intolerant $(51.1 \%$ internal intolerance and $34.3 \%$ external intolerance) [3]. 
These statistics need attention from all parties, because after all Generation $\mathrm{Z}$ is the generation that will continue the leadership relay in this country. Moreover, their attitudes and behavior related to tolerance, because the value of tolerance is an "expensive" value and needs to be maintained in order to maintain what is currently owned. Generation $\mathrm{Z}$ as the next generation of this nation has characteristics that need to be considered, such as being less committed, often thinking short, practical, and not complicated [4]. In order to know and understand in depth the tolerance of the nation's $\mathrm{Z}$ generation, a holistic study is needed regarding this matter. Through this study, the author aims to find out how the concept of national tolerance is owned by Generation $\mathrm{Z}$ in the life of the nation and state.

\section{THEORETICAL REVIEW}

\subsection{Tolerance}

Tolerance is an attitude or human behavior that follows the rules, where a person can respect, respect the behavior of others [4]. Based on historical records owned by Indonesia where various forms of culture that are very thick with pluralism have collaborated very beautifully, coexisting between tribes, religions, races, customs and cultures, which is referred to as tolerance [5].

Tolerance in the socio-cultural and religious context means attitudes and actions that prohibit discrimination against groups that are different or unacceptable to the majority in a society [5]. It is this experience of being together with other humans that connects us to "tolerance", which is the practice of respecting others while constantly looking for common ground [6]. An attitude of trust and tolerance has a very positive impact on national integrity and social harmony [7]. Tolerance in people's lives can be reflected in how one perceives friendship between ethnic groups and religions as well as activities organized by a group of people from different ethnic groups or religions [7]. The tolerant character becomes the foundation to be built in the life of this pluralistic nation in order to glue existing differences. With tolerance that has become the nation's character, any differences will be put in context as a part that must be respected [8]

\subsection{Nationality}

Merriam-Webster dictionary [9] provides a definition that nationality is a community of people composed of one or more nationalities and possessing a more or less defined territory and government,selain itu kebangsaan (nation) juga memiliki makna a territorial division containing a body of people of one or more nationalities and usually characterized by relatively large size and independent status.

Nationalism (Nationalism) is an ideology that creates and maintains the sovereignty of a country (nation) by realizing the concept of a common identity for a group of people. In addition, nationalism can also be understood as a sense of love of citizens for their homeland or country [10].

Same at these statement above, Smith [11] states that nationalism (nationality) is an ideology or understanding that places the nation at the center of the problem and seeks to enhance its existence as a movement to achieve and maintain autonomy, unity, and identity for a population, whose members are determined to form an actual nation or nation. potential.

\subsection{Z Generation}

Each generation that exists today has different characteristics, this is certainly influenced by many factors. This generational theory emerged based on an article written by a Hungarian sociologist named Mannheim. In an essay entitled "The Problem of Generation", the sociologist Mannheim introduces his theory of generation. According to him, humans in this world will influence each other and form the same character because they go through the same socio-historical period. That is, humans during the 2nd World War and post-WW2 humans must have different characters, even though they influence each other. [12].

Neil Howe and William Strauss [13] stated that this generation $\mathrm{Z}$ as the Homeland generation, they were born around 2005-2025, are now starting to arrive in American nurseries. Gen Xers (as parents) adopt a parenting style that is very protective of this generation, but half of their babies will have millennial parents. It is still too early to determine when the first birth year of this homeland generation, which will be clear.

Kurniawan [14] called generation $\mathrm{Z}$ as $\mathrm{i}$ Generation, net generation or internet generation. They have similarities with generation $Y$, but they are able to apply all activities at one time such as being active on social media using mobile phones, browsing with PCs, and listening to music using headsets. Whatever they do is mostly related to the virtual world. Since childhood they are familiar with technology and are familiar with sophisticated gadgets that indirectly affect their personality. 


\section{METHOD}

This study uses a qualitative approach with a case study method which was carried out at SMA Negeri 4 Bandung. This study aims to comprehensively understand the concept of generation $\mathrm{Z}$ tolerance. Through data collection techniques, interviews, observations and literature studies. The subjects of this study were students of class X and XI both in the science and Social studies programs at SMAN 4 Bandung. In the data processing technique, data reduction, data presentation, verification and triangulation are needed to produce valid and accountable data.

\section{RESULT AND DISCUSSION}

Based on the results of research that has been carried out by the author on the research subjects as Generation $\mathrm{Z}$ where they are currently high school students [15] through interview data collection techniques, it was found that generation $\mathrm{Z}$ is a generation that from the beginning they were born they were familiar with technology, especially those related to communication tool technology. Generation $\mathrm{Z}$ is always synonymous with a generation that is very attached to the internet, even when researchers ask important things in their lives (generation Z), one of the answers is quota or internet packages. The internet is something that cannot be separated from the life of generation $\mathrm{Z}$. Where all the needs that support learning activities, they look for with the help of the internet [16].

Their lives are never separated from digital information and have a life in cyberspace. They have a life between the real world and the virtual world. With these two lives, they certainly have something different from previous generations. Based on the results of the study, it was stated that they were more comfortable to explore themselves in the virtual world than in the real world. The reason is that those in cyberspace can explore the world without knowing who they are.

Bassiouni and Hackley [17] said that discuss a 2012-2013 study conducted in the United Kingdom on the media consumption of children between the ages of 5 and 16 . The study showed that 69 percent of the youth owned a mobile phone, 73 percent had their own PC or laptop, 60 percent used computers to go online an average of $1.5 \mathrm{~h}$ per day, and 84 percent had gaming consoles with the majority playing an average of $1.4 \mathrm{~h}$ per day.
The results of the study also state that Generation $\mathrm{Z}$ is a generation that has an open understanding compared to previous generations. This is certainly the basic capital of tolerance, especially tolerance in generation $Z$. This is evident from the attitudes and behavior of generation $Z$, especially those in SMA Negeri 4 Bandung both in class X and XI of the MIPA and IPS program, where there are no actions that lead to to things that smell intolerant. Even if there is, it is a "joking" fellow friend, and the friend does not feel being bullied, so the response he receives is to laugh and mock each other (not to insult).

The condition of diversity at SMAN 4 Bandung can also be said to be a heterogeneous school, in the sense that the school is a school that has diversity in terms of religion, race and culture. Even SMAN 4 Bandung itself is a school that implements an inclusive school, where people with disabilities can also study together with other students. Then, the conditions at SMAN 4 Bandung also in terms of diversity are reflected in the existence of a program where students who work as athletes both at the city and national levels can co-exist to study together with those who are regular.

Of course, if we analyze it in depth, it will cause a conflict and social jealousy for students. But what happened was that they were able to collaborate and work together regardless of who he was, what religion, ethnicity, race, culture and from what path he entered school.

This action was reinforced by the statement of the informant that Generation $\mathrm{Z}$ is a generation that is not easily offended (their language is Ga Baperan), this is what makes Generation $Z$ an open minded generation, a generation that easily accepts changes and they are able to quickly adapt to these changes. . Because true tolerance is an attitude or human behavior that follows the rules, where one can respect, respect the behavior of others [4].

One of the characteristics of those who are open minded is of course the basic capital for generation $\mathrm{Z}$ to be able to live in an ever-changing condition. According to them, tolerance is a condition where tolerance is respect for differences with limitations not to interfere in the lives of each individual. According to them, tolerance is a condition where they are able to live safely, peacefully and comfortably in the midst of their diverse lives. This is in line with what was conveyed by Nisvilyah [18] who says that social tolerance is tolerance that is oriented towards society. In a society that is diverse due to religious differences, it is recommended to 
establish peace and cooperate with people of different religions within predetermined limits. Then the attitude of tolerance in people's lives can also be reflected in how a person's perception of friendship between ethnic groups and religions as well as activities organized by a group of people from different ethnic groups or religions differs [19].

Their tolerance attitude is also reflected when they carry out a group activity, where they are given tasks by the subject teacher to discuss and work on a project. According to them, when they are going to work in groups, they discuss what days should not disturb each of the group members, either for worship or other activities. This is of course as social capital in maintaining the integrity of the nation and state, where among them do not emphasize and impose their will, but instead provide opportunities by discussing so that no one feels disadvantaged or interferes with their worship time that is different from themselves. The attitude of tolerance is one of the manifestations of social capital in the cognitive aspect which is defined as an attitude of being willing to accept and appreciate the differences among community members [19].

The concept of national tolerance of Generation $\mathrm{Z}$ is explicitly not easy to understand, but if we analyze it comprehensively, we will find that Generation Z, which is predicted to be the leader of Indonesia in 2045, or in other terms, the Gold Generation, is reflected that tolerance is a form of tolerance. something very important, and they realized it. Tolerance is the most basic social capital, where with tolerance there will be togetherness and the end is the creation of comfort, peace and security in the life of the nation and state. Because in fact, according to them, if they want to live together, live in differences, the society that they want or aspire to in the fifth Pancasila principle will be realized.

If we study more deeply with the way of thinking of this generation $\mathrm{Z}$, then we will meet the concept of nation proposed by Renan [20] where nation is a matter of feeling, will (determination) solely to live together (le desir de vivre ensemble), which arises between a large group of people who had the same fate in the past, especially in shared sufferings. In this concept we can understand that the nation is an "awareness to live together", of course this does not look at what race, ethnicity, culture, and religion are.

Their national tolerance is also manifested where when they or their friends or anyone is treated unfairly, for example being bullied, or bullied, then they will not stay silent and just let it go. What they will do is help the bullied person by reminding the

bullied person not to do that. Even if they do not have power over it, then they feel resentful of the action. This means that Generation Z has social sensitivity, and is oriented towards social life, although in a way other than Generation $Z$ they do not understand it very well.

Finally, in terms of responding to a difference in their lives, as well as how the limits of tolerance that Generation $\mathrm{Z}$ has, they say there are several stages so that in the end they want to live side by side with those who are different. This can be seen in the following start:

Level 3

Level 2 Accept and want to

Appreciate \&

Respect others and

Level 1 treat others

understand

not to disturb

others

Figure.1 Stage of Tolerance

Based on the graph above, we can understand that the lowest national tolerance that is believed and understood by Generation $\mathrm{Z}$ is at level 1, which is where they understand that they are in a different society, so they have the principle not to disturb other people's lives. This means that they allow people who are different from themselves to carry out their activities, but Generation $\mathrm{Z}$ doesn't really care about it. Then in level 2, it is stated that they value respect for others and treat others properly. That is, at this second level, Generation $\mathrm{Z}$ begins to try to care more about the differences that exist, but only to the extent of respecting and respecting. Because at level 3 this is the peak of generation Z's national tolerance appears. Where in different conditions, they then try to understand, after that respect and appreciate then in the end they want to live side by side with differences without making a fuss about these differences.

\section{CONCLUSION}

Generation Z's national tolerance is a concept of tolerance that is believed by Generation $Z$ as the generation that will lead Indonesia in 2045. This is certainly an important concern for us to prepare for the right education pattern and the right approach for them. Because generation $\mathrm{Z}$ is unique where they have two different worlds, namely the real world and 
the virtual world (digital). They are more likely to be comfortable in their digital world. With regard to tolerance, generation $\mathrm{Z}$ has a unique concept of tolerance, where they have stages in accepting a condition that they consider to be different from their own and environmental conditions. At the first level they will try to understand the differences in a way not to interfere with the existing differences and tend not to care (one's own way). At the second level they start to care a little about the differences that arise, by starting to appreciate and respect and at the last stage they will and want to live side by side with the differences that occur in their lives.

\section{REFERENCES}

[1] CNN Indonesia, "Kronologi Siswi Sragen Diteror Karena Tak Berjilbab," Kamis, 09/01/2020 21:53 WIB, 2020. $\mathrm{https} / / / \mathrm{www} . \mathrm{cnnindonesia.com/nasional} / 202$ 00109213447-20-464063/kronologi-siswisragen-diteror-karena-tak-berjilbab (diakses Apr 07, 2020).

[2] R. Ahmad, "Mengenal Azyumardi Azra Dalam Pemikiran Islam," Anal. Islam., vol. 2, no. 2, hal. 352-370 Sekilas, 2013.

[3] R. E. Saputra, "Api Dalam Sekam Keberagamaan Generasi Z," Jakarta, 2018. [Daring]. Tersedia pada: ppim.uinjkt.ac.id.

[4] A. Bakar, "Konsep toleransi dan kebebasan beragama," Toler. Media Komun. Umat Bergama, vol. 7, no. 2, hal. 123-131, 2015.

[5] E. Digdoyo, "Kajian Isu Toleransi Beragama, Budaya, dan Tanggung Jawab Sosial Media," J. Pancasila dan Kewarganegaraan, vol. 3, no. 1, hal. 42-60, 2018.

[6] Pusat Studi Islam dan Kenegaraan Indonesia (PSIK-Indonesia), Indonesia Zamrud Toleransi, no. 11. Jakarta: PSIK-Indonesia, 2017.

[7] Pusat Data dan Statistik Pendidikan dan Kebudayaan (PDSPK) Kementerian Pendidikan dan Kebudayaan Republik Indonesia, Analisis Faktor-Faktor Yang Mempengaruhi Sikap Toleransi DI Indonesia. Jakarta: PDSPK Kemendikbud RI, 2017.

[8] I. Y. M. Dewi dan D. Stefany, "Pengembangan Karakter Toleran Siswa Melalui Pendekatan Saintifik Dalam Pembelajaran Ipa di SDN Pajagalan 2
Kabupaten Sumenep," Fikrotuna; J. Pendidik. dan Manaj. Islam, vol. 10, no. 2, 2019, [Daring]. Tersedia pada: http://ejournal.kopertais4.or.id/madura/index .php/fikrotuna/article/view/3781.

[9] Merriam-Webster Dictionary, "Nation," 31 Desember 2019, 2019. https://www.merriamwebster.com/dictionary/nation (diakses Jan 05, 2020).

[10] M. Kiptiah, "Internalisasi Nilai Adat Badamai Sebagai Upaya Resolusi Konflik Dalam Memperkuat Komitmen Kebangsaan Pada Masyarakat Banjarmasin," Sekolah Pascasarjana Universitas Pendidikan Indonesia, 2018.

[11] A. . Smith, Nasionalisme Teori, Ideologi, Sejarah. Jakarta: Erlangga, 2003.

[12] A. Adam, "Selamat Tinggal Generasi Milenial, Selamat Datang Generasi Z," 28 April, 2017. https://tirto.id/selamat-tinggalgenerasi-milenial-selamat-datang-generasiz-cnzX (diakses Jan 02, 2020).

[13] N. Howe dan W. Strauss, "The Next 20 Years: How Customer and Workforce Attitudes Will Evolve," Harv. Bus. Rev., hal. 41-52, 2007, [Daring]. Tersedia pada: hbr.org.

[14] R. Kurniawan, "Teori Generasi (Generation Theory)," 28 Maret, Bandung, 2019.

[15] E. Saputra, "Menelisik Dinamika Radikalisme Gen Z Perempuan di Facebook," Islam. J. Stud. Keislam., vol. 14, no. 1, hal. 103-125, 2019, doi: 10.15642/islamica.2019.14.1.103-125.

[16] D. L. Purwodani, Sulton, dan H. Praherdhiono, "Prospek Pengembangan Lingkungan Belajar Digital untuk Generasi Z di Era Industri IV," J. Pendidik. Teor. Penelitian, dan Pengemb., vol. 3, no. 7, hal. 930-934, 2018, [Daring]. Tersedia pada: http://journal.um.ac.id/index.php/jptpp/

EISSN: $\quad 2502-471 \mathrm{X}$ DOAJSHERPA/RoMEO-Google ScholarIPI\%0AJurnal.

[17] D. Bassiouni dan H. C, “'Generation Z' children's adaptation to digital consumer culture: a critical literature review," $J$. ofCustomer Behav., vol. 13, no. 2, 2014, doi: 10.1362/147539214x14024779483591.

L. Nisvilyah, "Toleransi Antar Umat 
Beragama dalam Memperkokoh Persatuan dan Kesatuan Bangsa (Studi Kasus Umat Islam dan Kristen Dusun Segaran Kecamatan Dlanggu Kabupaten Mojokerto)," Kaji. Moral dan Kewargenegaraan, vol. 2, no. 1, hal. 382-396, 2013.

[19] Dwi Winanto, M. Dokhi, T. H. Siagian, R. Rahani, dan Sukim, Analisis Faktor-Faktor Yang Mempengaruhi Sikap Toleransi di Indonesia. Jakarta: PDSPK Kemdikbud RI, 2017.

[20] E. Renan, Apakah Bangsa Itu? (Qu'est Ce Qu'une Nation?), Pertama. Bandung: Penerbit Alumni, 1994. 